\title{
BMJ Open Sociodemographic factors, level of physical activity and health-related quality of life in adults from the north- east of São Paulo, Brazil: a cross- sectional population study
}

\author{
Nicoly Machado Maciel, ${ }^{1}$ Marta Helena Souza De Conti, ${ }^{2}$ \\ Sandra Fiorelli Almeida Penteado Simeão, ${ }^{3}$ Caio Vitor dos Santos Genebra, ${ }^{4}$ \\ José Eduardo Corrente, ${ }^{5}$ Alberto De Vitta ${ }^{6}$
}

To cite: Maciel NM, De Conti MHS, Simeão SFAP, et al. Sociodemographic factors, level of physical activity and healthrelated quality of life in adults from the north-east of São Paulo, Brazil: a cross-sectional population study. BMJ Open 2018;8:e017804. doi:10.1136/ bmjopen-2017-017804

- Prepublication history for this paper is available online. To view these files, please visit the journal online (http://dx.doi. org/10.1136/bmjopen-2017017804).

Received 19 May 2017

Revised 12 July 2017

Accepted 2 August 2017

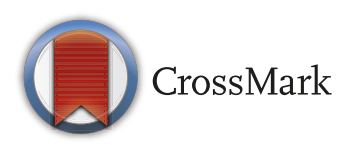

For numbered affiliations see end of article.

Correspondence to MSc Nicoly Machado Maciel; ni-maciel@hotmail.com

\section{ABSTRACT}

Objective To verify the association among

sociodemographic variables, physical activity level and

health-related quality of life in adults aged 20 years and over.

Methods Population-based study, with household sample by clusters. The dependent variables were the PCS and MCS scores of the instrument 36 -Item Short-Form Health Survey (SF-36), the independent variables were gathered in sociodemographic characteristics and the level of physical activity. Absolute and relative frequency distributions were used for categorical variables and bivariate analysis, using Student's t-test and ANOVA and multivariate using

non-conditional logistic regression.

Results Of the 600 interviewees, the mean PCS score for men was 80.2 and for women 74.6 , while for MCS, $83.8( \pm 16.9)$ and $76.5( \pm 23.3)$, for men and women, respectively. Women tend to report lower scores than men in all domains: $\operatorname{men}(\mathrm{OR}=4.83)$ and women $(\mathrm{OR}=4.80)$ were older $(\mathrm{OR}=4.34)(\mathrm{OR}=3.57)$ and sedentary women $(\mathrm{OR}=1.90)$ were associated with lower PCS scores, while older men $(\mathrm{OR}=3.96)$ and widowed and separated' $(\mathrm{O}=3.03)$ had lower MSC scores.

Conclusion HRQoL was associated with advancing age and schooling, in both sexes, sedentary women and widowed and separated men.

\section{INTRODUCTION}

Health-related quality of life (HRQoL) is a multidimensional construct that assesses an individual's perception of his or her own condition of well-being in the spheres of work, culture and values, including their personal goals, expectations and interests. ${ }^{1}{ }^{2}$ HRQoL is considered an indicator to evaluate the health status of populations and to study the results of health systems ${ }^{3}$ and of therapeutic interventions used in a given population, ${ }^{4}$ cases of morbidity and mortality in the general population, and as a complement to clinical investigations.
Strengths and limitations of this study

- The scarcity of studies on HRQoL conducted among adults in the general population, without any specific pathology and not institutionalised.

- The proper methodology to calculate the sample size and the use of structured methods for the collection and interpretation of data.

- The causality of relationships cannot be taken under consideration because of the cross-sectional characteristic study.

- IIInesses or chronic conditions were not included as covariates.

The HRQoL is evaluated by a specific instrument, the Medical Outcomes Study Questionnaire 36-Item Short Form Health Survey (SF-36), translated and validated into Portuguese. ${ }^{5}{ }^{6}$ Such an internationally recognised instrument has the advantage of already possessing its attested validity and psychometric qualities, as well as allowing comparisons of its results among different populations and presenting a multicultural approach.

Previous studies have shown the relationship between sociodemographic factors and physical activity level and HRQoL, showing that increasing age,${ }^{47}$ low schooling, ${ }^{78}$ female $\operatorname{sex}^{9}$ and sedentary lifestyle ${ }^{9}$ presented a decrease in HRQoL.

In Brazil, there is a great shortage of studies on HRQoL conducted among adults of the general population, without any specific pathology and non-institutionalised, although there is a growing recognition of the importance of generating data related to the health and HRQoL of this population stratum, and previous studies have evaluated 
HRQoL in specific populations, usually institutionalised and/or carriers of some chronic disease, including chronic end-stage renal disease in ambulatory haemodialysis, arterial hypertension, undergoing repair of hip fracture, living with HIV/AIDS and in a household survey of elderly residents in the state of São Paulo. ${ }^{5}$

With the increasing population of adults over 20 years of age in middle-income countries, such as Brazil, knowledge of how sociodemographic factors and physical activity affect the quality of life can have a significant economic and social impact, both in the family and economic context for the country. ${ }^{10}{ }^{11}$ In addition, these variables influence the behaviour of their dependents, the medium/long-term morbidity pattern may also have consequences for future generations.

Thus, the objective of this study was to verify the association among sociodemographic variables, physical activity level and HRQoL in adults aged 20 years and over.

\section{METHODS}

A cross-sectional study carried out in the urban area of Bauru, SP, Brazil, a city with approximately 316064 inhabitants, 207021 of them over 20 years old.

The age and gender groups (called sample domains) were first defined with a minimum number of individuals per sample, in order to allow further analysis. Six sample domains were determined: 20- to 35-year-old men; 20- to 35-year-old women; 36- to 59-year-old men; 36 - to 59-year-old women; 60-year-old and older men; and 60 -year-old and older women.

The sample size calculation was based on the following premises: an estimated proportion of $50 \%$ of the population subgroups, since this is the maximum variability that leads to obtaining conservative sample sizes; a $95 \%$ confidence level in the estimation of confidence intervals; a $10 \%$ sampling error, indicating that the amplitude between the estimated sample and the population parameter should not exceed this value; and a design effect (deff) equal to 2. Therefore, the sample size for each group was at least 200 individuals (100 male and 100 female), totalling 600 participants.

Sampling was drawn from a two-stage cluster. The primary sampling units (PSUs) were the census tracts, and the secondary sampling units were the residences. The PSUs were drawn by systematic sampling with a probability proportional to their sizes. ${ }^{6}$ The sampling units were obtained from the National Survey of Household Samples from $2011,{ }^{6}$ which produced an address list of private homes for each census tract. A total of 50 urban census tracts were drawn from the 476 identified ones.

The number of households to be drawn from each sampling domain ${ }^{6}$ was determined, and the ratio between the average number of individuals and the number of households was then calculated. Therefore, it was decided that about 12 households should be visited for every census tract. These households were systematically drawn and all individuals residing in them were considered eligible for the interviews. A new household was randomly selected in case of refusal.

The individuals who were not located after four visits (of which at least one was at night and one on the weekend), including those who were not found, due to travelling, were considered as loss. The individuals who refused to answer the questionnaire by personal choice were considered as refusals.

Individuals who were living in institutions such as nursing homes and prisons, and those who were unable to answer the questionnaire were excluded from the study. The elderly underwent the Mini-Mental State Examination at the beginning of the interview, so their cognitive state, as well as the reliability of their answers, could be assessed. Participants who scored below 27 points ${ }^{6}$ were considered with cognitive loss and, therefore, have been excluded.

Interviews were conducted by 10 interviewers, senior physical therapy students. All had undergone theoretical and practical training, which included home approach, interviewing techniques and issues related to the research tool. A pilot study was performed as part of the training, and the fieldwork was supervised by the researchers involved in the study.

Data was collected from February to June 2012. After the interviews, the questionnaires were coded by the interviewers and revised by the researcher in charge. The supervisors also conducted a quality control, which consisted of administering reduced questionnaires with $10 \%$ of the respondents.

To evaluate the quality of life, we used the questionnaire Medical Outcomes Study 36 - Item Short-Form Health Survey (SF-36). This 36-item tool addresses both physical and mental/emotional concepts, including scales that measure eight domains: physical functioning - PF (presence and extent of limitations related to physical functioning); role limitations due to physical problems - RPP (limitations regarding the type and amount of work); pain (presence and intensity of pain and its influence in the daily life activities); general health perception - GHP (perception of the individual regarding overall health); vitality - VIT (it considers levels of fatigue and energy); role limitations due to social problems - RLS (integration of the individual in social activities); limitations due to emotional problems - RLE (psychological aspects impact on the person's well-being); and mental health - MH (anxiety, behavioural alteration, depression and psychological well-being). Each of these domains, analysed individually, received a score of zero to 100, with zero indicating the worst possible HRQoL level and 100 the best condition. The instrument was chosen because it is validated in Brazilian culture, being of simple interpretation, with direct questions, easy administration and understanding, and excellent reliability, presenting Cronbach's $\alpha$ of $0.90 .^{12}$

The verification of the physical activity level was performed using the International Physical Activity Questionnaire (IPAQ), which contains questions regarding 
weekly frequency and duration in minutes per day of vigorous, moderate and walking physical activity. The questionnaire was duly validated for the Brazilian population obtaining coefficient of validation for the short version of $r=0.75 .{ }^{13}$ A cut-off point of $150 \mathrm{~min}$ per week was used for classifying the participants as active $(150 \mathrm{~min} / \mathrm{wk}$ or more) or insufficiently active (below $150 \mathrm{~min} / \mathrm{wk}){ }^{14}{ }^{15}$

Demographic characteristics (age, sex, skin colour) and socioeconomic characteristics (income and marital status) were evaluated through a pre-coded questionnaire with closed questions. Gender was categorised as female and male, age at three age groups, marital status (single, married, widowed/separated) and schooling was defined in years of study ( 0 to 4 years, 5 to 8 years, 9 to 11 years and 12 years or more).

The skin colour variable (white, black, brown) was also collected by the interviewers and the income was indicated in minimum wages (up to $3 \mathrm{MW}$, from 4 to $9 \mathrm{MW}$ and 10 or more MW), determined according to the criteria of the Brazilian Institute of Geography and Statistics. ${ }^{16}$

The normality of the SF-36 scores was examined and all of them were satisfactory (lower than one value distortion). The analysis was performed by a descriptive and then an analytical approach. Distributions of absolute and relative frequencies for categorical variables and the analytical approach were made in the descriptive approach. The bivariate analysis, in analytical approach, was performed using the Student's t-test and ANOVA. Multivariate analysis was performed using logistic regression, allowing simultaneous control of factors that take into account the hierarchy of determining the QoL. The design effect with a value of 1.4 was considered in the analysis. The proposed model for the mentioned hierarchy consisted of three levels: the first, in which demographic variables are inserted (gender, age and skin colour); the second, in which socioeconomic variables (income and education) and demographic (marital status) are inserted; and the third, which covered the behavioural variables (low physical activity, smoking). The effects of the variables of the first level were self-controlled; the second level effects were controlled between them and the first level; and the third level effects were controlled between them and the two previous levels.

The process of stepwise backward was used for the selection of variables that remained in the logistic regression model: all variables with $\mathrm{P}<0.05$ remained in the final model. It was considered the $5 \%$ significance level for all tests. Summaries of the physical and mental components were used for logistic regression analysis in which the cut-off point was the mean values of the sample divided into two groups: individuals who have values equal or higher than the average; and individuals who scored below average. ${ }^{1718}$

\section{RESULTS}

The 600 respondents, 300 men and 300 women, were distributed in the age groups 20-35, 36-59 and 60 or older, with an average age of 47.3 years $( \pm 18.2)$ distributed between 20 and 96 years. Regarding marital status, $57.5 \%$ (345) were married; white coloured skin $80.0 \%$ (480); studied from 9 to 11 years $(40.7 \%-244) ; 65.0 \%$ (390) had an income between 1 and 3 MW and $65.0 \%$ (390) of the participants were sedentary, while $35.0 \%$ (210) were active.

Regarding the eight domains of HRQoL, women have lower average scores than men in all domains. The average of the four physical domains for men was $80.2( \pm 24.0)$ and for women $74.6( \pm 27.6)$, while in the psychological domain the averages were $83.8( \pm 16.9)$ and $76.5( \pm 23.3)$ for men and women, respectively. The men's average values ranged from $66.7( \pm 10.4)$ in the vitality domain to $93.0( \pm 17.7)$ in the social functioning domain in the individual analysis. Women's scores showed a variation of 63.1 $( \pm 13.9)$ up to $89.1( \pm 21.5)$ in the same domains.

The results found in the application of the SF-36 regarding the physical domains - physical functioning, according to the variables age, race, marital status, education, income and level of physical activity in relation to male and female gender, are shown in tables 1 and 2, in which the average scores of younger individuals, in both genders, were higher than the other two age groups and those in the higher age group had the lowest scores, although all higher than 62.3 can be verified. Higher scores for women were presented only in the general health domain, age 36 to 59. All comparisons made for the variable age were statistically significant.

Statistically significant differences were observed in the analysis of the variable ethnicity in the physical functioning, physical role and summary of the physical components domains, unlike the general health domain, with proximate average values (66.0 to 75.7). Men's scores were higher than women's, except in the black ethnicity and in the general health domain in white women.

The average of the marital status variable showed that single individuals, in both genders, have higher average scores for all domains, while the lowest values belong to separated/divorced people, and all comparisons are statistically significant. The male individuals showed higher average scores for all domains, in relation to women, except for the general health domain for married and separated/divorced people.

In table 2, the values of the domains are highlighted for the education variable which was higher in the range of 9 to 11 years and lower in the range of 0 to 4 years, for men. For women, the highest scores were in the range over 12 and lower in the first track, all showing significant differences. The men's average scores were always higher, except for the role physical domain range of 5 to 8 years of schooling and general health domain with the tracks 0 to 4,9 to 11 and more than 12 years, which were higher for women.

The analysis of the income variable pointed out that men have higher average scores than women, except in the body pain domain in the range 4 to $9 \mathrm{MW}$ and general health domain in the range of 10 or more MW. 


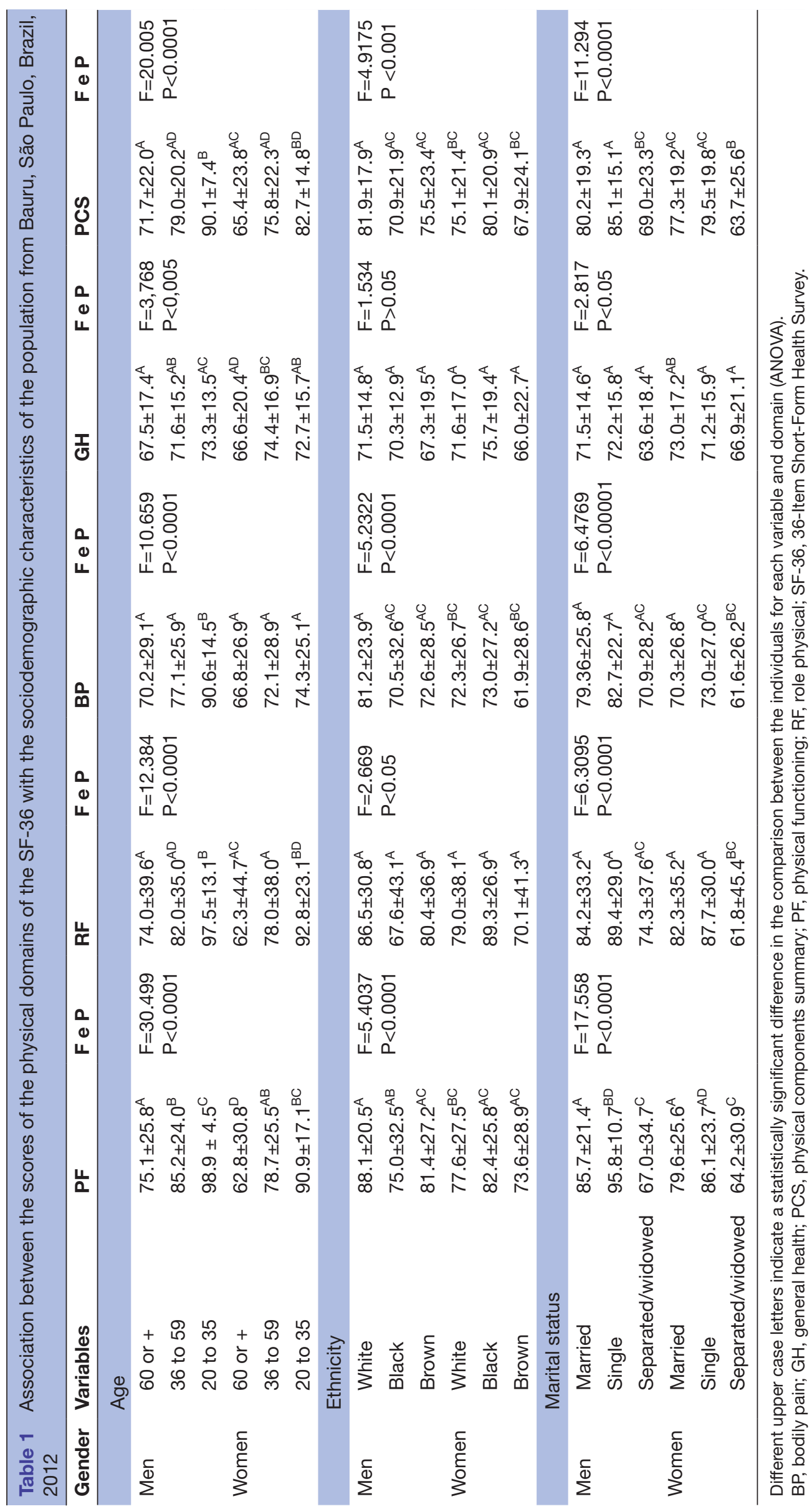




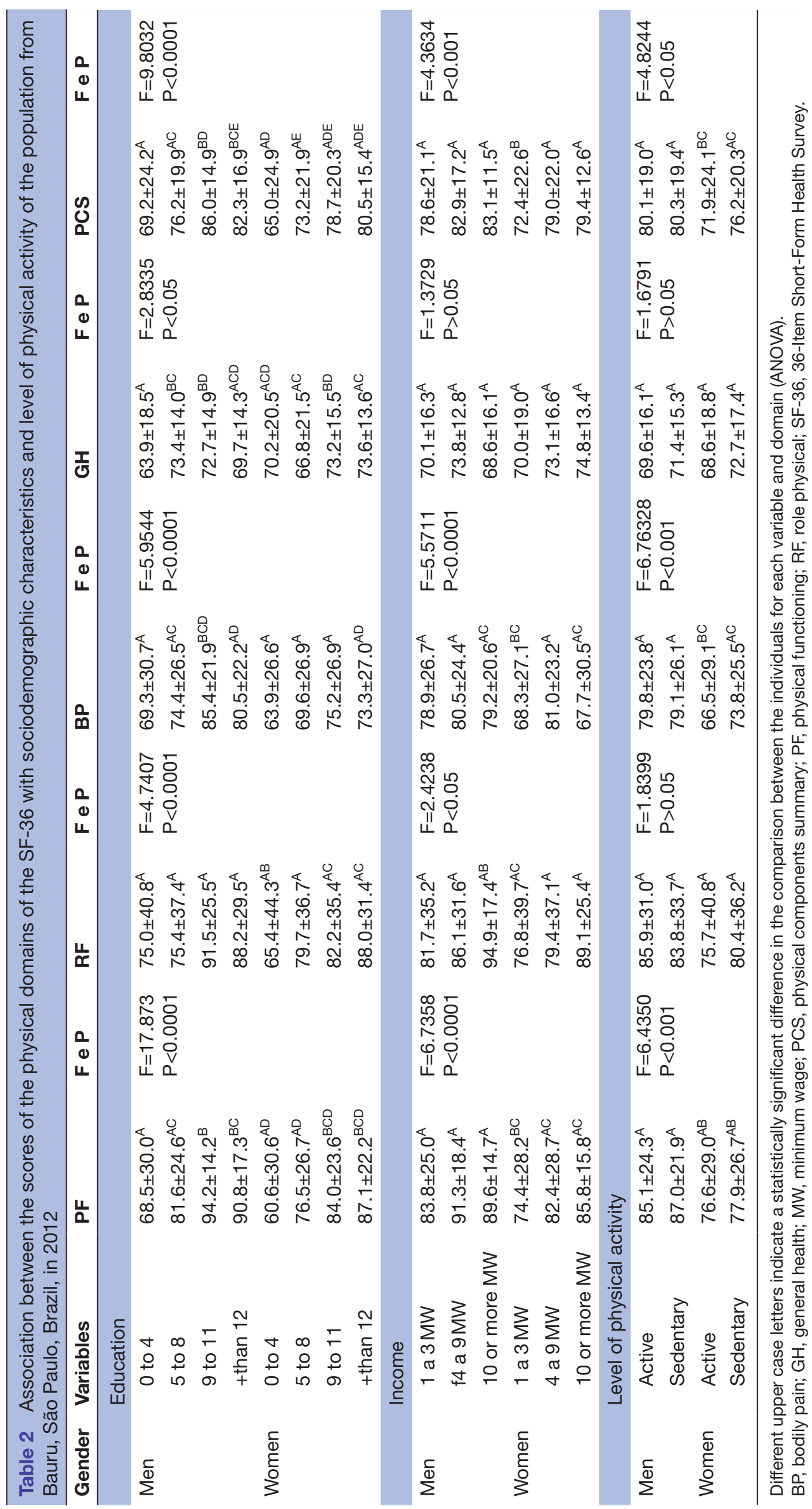


The general health domain was the only one that did not show statistically significant difference.

The level of physical activity was dichotomised into active and sedentary and again the men's scores were higher than women's in all areas, except in the general health domain compared with sedentary women. All sedentary women had higher scores than the active ones, repeating the same for men, except in the physical role and body pain domains. The physical role and general health domains were not statistically significant.

Regarding the mental/emotional domains of the SF-36, the results can be checked in tables 3 and 4. Similarly to the physical domains, all the scores of the psychological/ social domains, regarding the variable age, were higher for men. As for age groups, it was verified smaller values for more advanced ages, except in vitality that has its lowest values in the range 36 to 59 years in both genders. The variations between the observed values showed statistically significant differences in all domains.

The results regarding ethnicity were well diversified for men, showing a standard only for women, which had the lowest HRQoL values for the brown skin colour. Due to this fact, all the domains showed statistical significance. The statistical difference is maintained in the analysis of variable marital status and the results of the physical domain repeated partially, that is, single individuals of both genders had higher scores. Married women showed lower values than men in all domains and the comparisons were significant.

Table 4 presents the results of the educational variables, income and level of physical activity. For the variable education there were greater QoL values in the ranges with a longer period of studies, that is, 9 to 11 and more than 12 years. Men had higher average scores than women except for the social functioning domain in the more than 12 years group, all showing significant differences.

As for income, repeating the observed for other domains, men showed higher average scores than women, except in the social functioning and mental health domains in the range of 10 or more. All comparisons between the responses of the variables and the domains were statistically different.

Regarding the level of physical activity, men's scores were higher than those of women in all areas. Unlike physical domains, all active (men and women) had higher scores than sedentary. The social functioning domain did not show a tatistically significant difference. It is noteworthy that the major differences between the genders' averages were found in the emotional role and mental health domains, having women almost 10 points less than men.

In a regressive analysis (table 5), it was noted that the PCS is associated with older men ( $\mathrm{OR}=13.82,95 \% \mathrm{CI}$ 5.87 to 32.75$)$ and older women $(\mathrm{OR}=4.80,95 \%$ CI 2.63 to 8.77$)$, with men $(\mathrm{OR}=4.34,95 \% \mathrm{CI} 1.85$ to 10.00$)$ and women with low education $(\mathrm{OR}=3.57,95 \% \mathrm{CI} 1.61$ to 7.69) and sedentary women (OR=1.90, 95\% CI 1.12 to 3.23). The MCS joined with older men ( $\mathrm{OR}=1.87,95 \% \mathrm{CI}$
1.03 to 3.40$)$ and older women $(\mathrm{OR}=3.96,95 \% \mathrm{CI} 1.61$ to 9.74$)$ and with the widowed and separated $(\mathrm{OR}=3.03$, $95 \%$ CI 1.29 to 7.14 )

\section{DISCUSSION}

The mean PCS score for men was 80.2 and for women 74.6, while for MCS $83.8( \pm 16.9)$ and $76.5( \pm 23.3)$ for men and women, respectively. Women tend to report lower scores than men in all domains, the advancement of age negatively affects SF-36 scores, that the less educated and sedentary women had low PCS scores and being widowed and separated was associated with lower MSC.

In this study, the mean values of PCS and MCS were similar to the survey performed in southern Brazil ${ }^{5}$ and higher than other surveys. ${ }^{9} 1920$ These differences are related to the socioeconomic and cultural conditions among the Brazilian regions. A favourable point of the present study is related to the representativeness of the general population in relation to the socioeconomic classes, similar to the study 'Social Dimensions of Inequalities ${ }^{16}$ in Brazilian households and, unlike the one in the south of Brazil that was underrepresented by the general population in relation to the lower socioeconomic classes.

In spite of the limitations and precautions that must be taken to compare these results with the values of other Latin American countries, the standard of scores of all HRQoL domains of the population of Bauru was similar to those of Mexico ${ }^{21}$ and larger than those of Colombia ${ }^{22}$ and Peru. ${ }^{23}$

Lower levels of women's PCS and MSC scores were verified in national level. ${ }^{59}$ Some elements may explain these differences in the perception of HRQoL by women. First, the traditional role of women as responsible for the health of their children and even husbands and other family members, often to the detriment of their own health, the more sensitive perception of serious events also adds to this phenomenon and the educational and occupational structure. ${ }^{2425}$

It was observed in the present study that increasing age affects negatively the PCS and MCS of HRQoL, in both sexes, similarly to other studies. ${ }^{59} 19$ The association between increased age and low PCS scores can be explained by the fact that along with advancing age comes a decrease in physical capacity, a higher incidence of chronic diseases and functional dependence. Difficulties in locomotion, in the handling of instruments or in the maintenance and adaptation of postures in the different tasks of daily life compete for the reduction in the autonomy of the individual. It can be said that in the diversity inherent in the quality of life, there is a basic element which is interconnected with all others - the ability to perform body movements efficiently. If this element is compromised, quality will be impaired. ${ }^{26}$

Regarding MSC, it has been described as 'non-linear' (with middle-aged respondents often having relatively low scores on mental health and 'older people' having better or greater emotional well-being). The elderly seem 


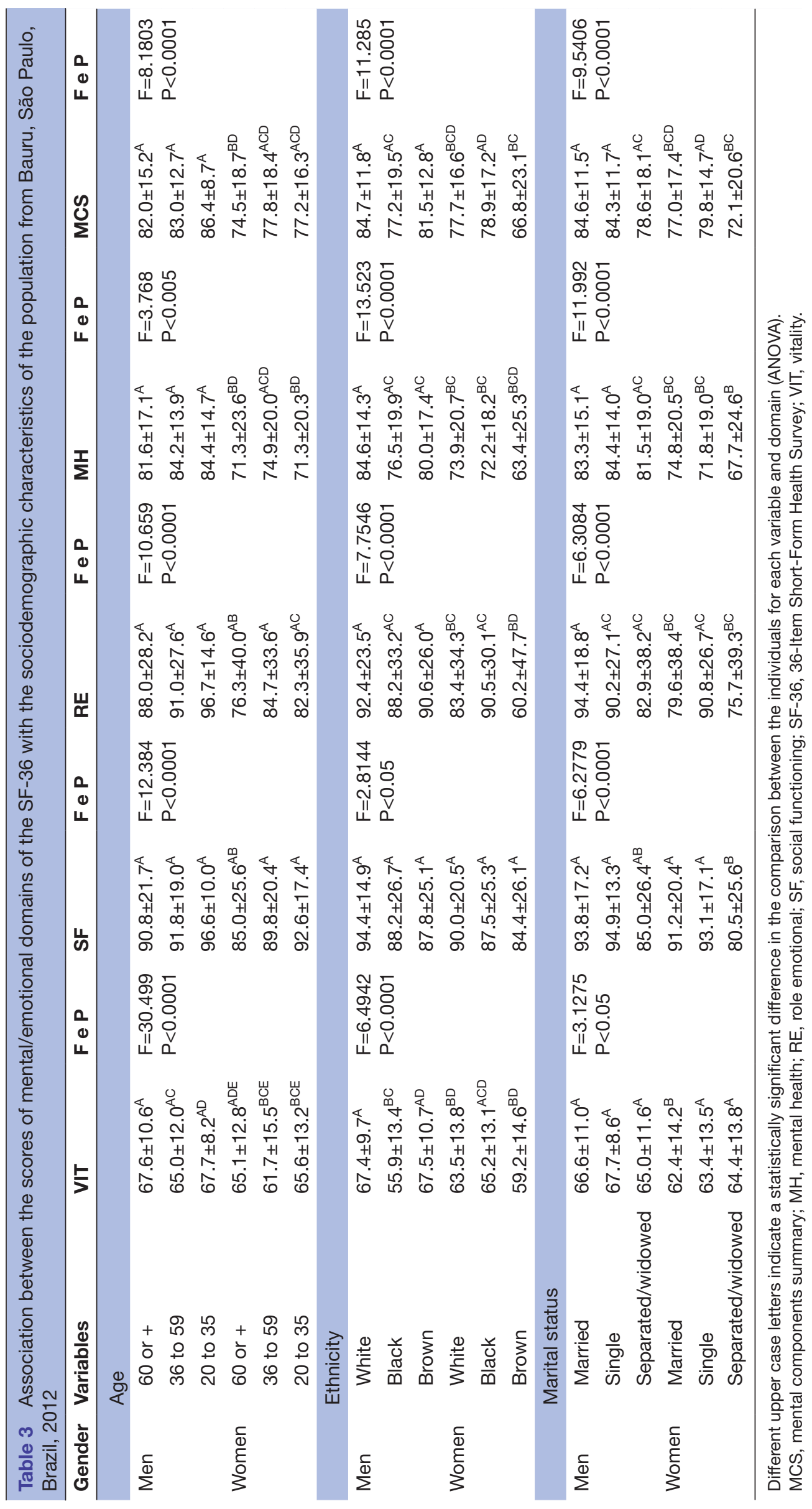




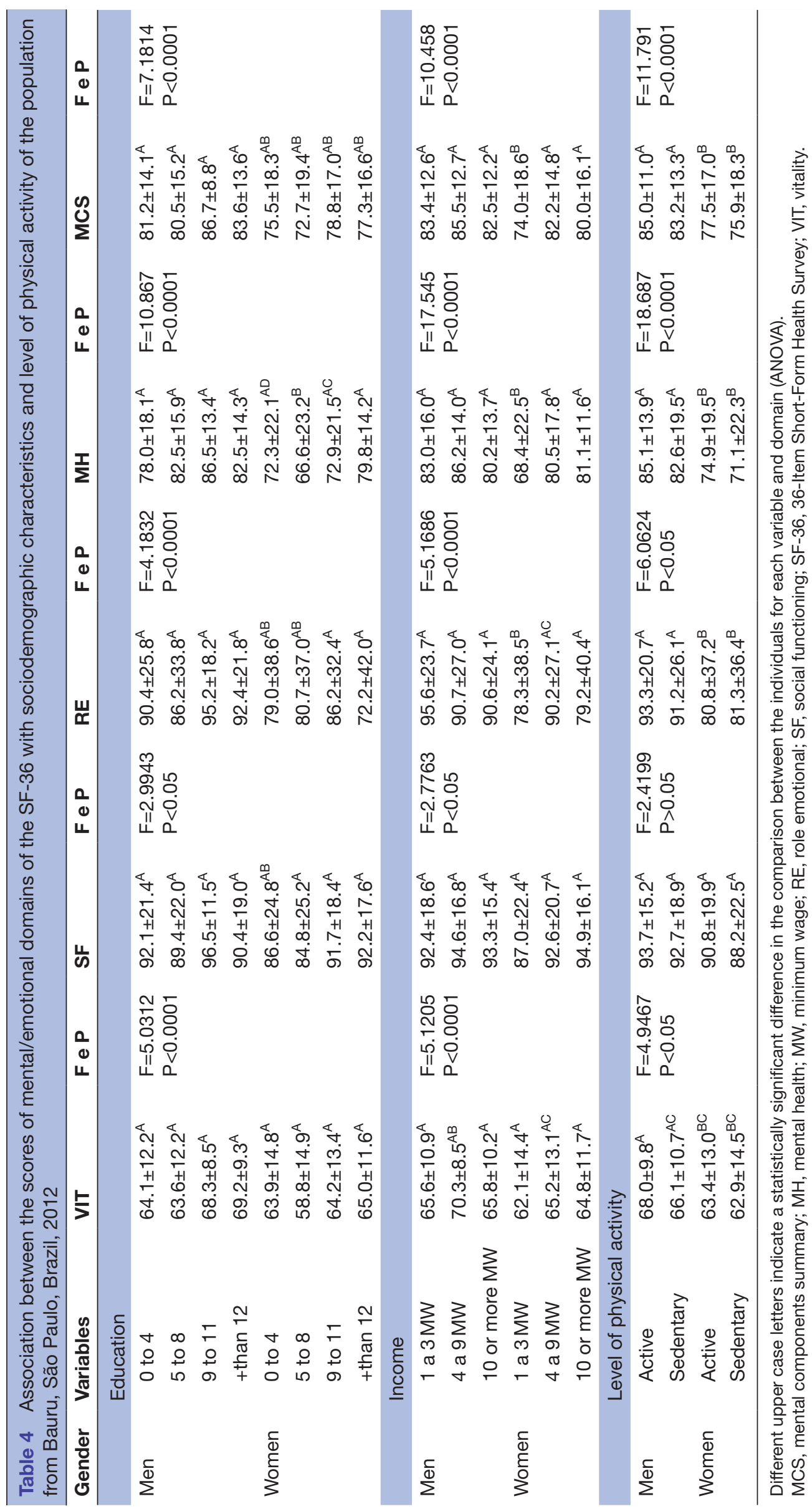


Table 5 Results of the logistic regression analysis for the PCS and MCS variables. Bauru, São Paulo, Brazil, 2012

\begin{tabular}{|c|c|c|c|c|}
\hline \multirow[b]{2}{*}{ Characteristics } & \multicolumn{2}{|c|}{ PCS } & \multicolumn{2}{|c|}{ MCS } \\
\hline & $\begin{array}{l}\text { Male } \\
\text { OR (IC 95\%) P }\end{array}$ & $\begin{array}{l}\text { Female } \\
\text { OR (IC 95\%) P }\end{array}$ & $\begin{array}{l}\text { Male } \\
\text { OR (IC 95\%) P }\end{array}$ & $\begin{array}{l}\text { Female } \\
\text { OR (IC 95\%) P }\end{array}$ \\
\hline \multicolumn{5}{|l|}{ Age } \\
\hline 20 to 35 & 1 & 1 & 1 & 1 \\
\hline 36 to 59 & $\begin{array}{l}2.02 \text { (1.14 to } 3.53 \text { ) } \\
0.01\end{array}$ & $\begin{array}{l}3.30 \text { (1.87 to } 5.89) \\
0.0001\end{array}$ & $\begin{array}{l}1.45 \text { (0.72 to } 2.93) \\
0.29\end{array}$ & $\begin{array}{l}1.34(0.75 \text { to } 2.39) \\
0.30\end{array}$ \\
\hline 60 or more & $\begin{array}{l}13.82(5.87 \text { to } 32.75) \\
0.0001\end{array}$ & $\begin{array}{l}4.80 \text { (2.63 to } 8.77) \\
0.01\end{array}$ & $\begin{array}{l}3.96 \text { (1.61 to } 9.74) \\
0.003\end{array}$ & $\begin{array}{l}1.87(1.03 \text { to } 3.40) \\
0.03\end{array}$ \\
\hline \multicolumn{5}{|l|}{ Marital status } \\
\hline Married & 1 & 1 & 1 & 1 \\
\hline Single & $\begin{array}{l}0.49(0.20 \text { to } 1.17) \\
0.10\end{array}$ & $\begin{array}{l}0.88 \text { (0.42 to } 1.84) \\
0.74\end{array}$ & $\begin{array}{l}0.93(0.44 \text { to } 1.97) \\
0.86\end{array}$ & $\begin{array}{l}0.98 \text { (0.47 to } 2.06) \\
0.97\end{array}$ \\
\hline Divorced/widowed & $\begin{array}{l}0.49(0.20 \text { to } 1.13) \\
0.09\end{array}$ & $\begin{array}{l}0.60(0.31 \text { to } 1.16) \\
0.13\end{array}$ & $\begin{array}{l}3.03(1.29 \text { to } 7.14) \\
0.01\end{array}$ & $\begin{array}{l}0.68(0.35 \text { to } 1.31) \\
0.26\end{array}$ \\
\hline \multicolumn{5}{|l|}{ Education } \\
\hline More than 12 years & 1 & 1 & 1 & 1 \\
\hline $\mathrm{n} 9$ to 11 years & $\begin{array}{l}1.38 \text { (0.84 to } 3.93) \\
0,12\end{array}$ & $\begin{array}{l}1.03(0.50 \text { to } 2,13) \\
0,92\end{array}$ & $\begin{array}{l}1.49 \text { (0.55 to } 3.62) \\
0.46\end{array}$ & $\begin{array}{l}1.68(0.82 \text { to } 3.45) \\
0.15\end{array}$ \\
\hline 5 to 8 years & $\begin{array}{l}2.50(1.14 \text { to } 5.58) \\
0,02\end{array}$ & $\begin{array}{l}2.22(1.02 \text { to } 5.00) \\
0,04\end{array}$ & $\begin{array}{l}0.54(0.21 \text { to } 1.39) \\
0.20\end{array}$ & $\begin{array}{l}0.77 \text { (0.35 to } 1.65) \\
0.50\end{array}$ \\
\hline 0 to 4 years & $\begin{array}{l}4.34 \text { (1.85 to } 10.00) \\
0.01\end{array}$ & $\begin{array}{l}3.57 \text { (1.61 to } 7.69) \\
0.02\end{array}$ & $\begin{array}{l}0.60(0.22 \text { to } 1.65) \\
0.33\end{array}$ & $\begin{array}{l}1.08(0.50 \text { to } 2.31) \\
0.84\end{array}$ \\
\hline \multicolumn{5}{|l|}{ Ethnicity } \\
\hline White & 1 & 1 & 1 & 1 \\
\hline Black & $\begin{array}{l}2.42 \text { (1.26 to } 4.63) \\
0008\end{array}$ & $\begin{array}{l}4.25(1.19 \text { to } 15.13) \\
0.02\end{array}$ & $\begin{array}{l}0.96 \text { (0.24 to } 3.76) \\
0.96\end{array}$ & $\begin{array}{l}2.86(0.88 \text { to } 9.03) \\
0.08\end{array}$ \\
\hline Brown & $\begin{array}{l}0.58 \text { (0.19 to } 1.81) \\
0.35\end{array}$ & $\begin{array}{l}2.03 \text { (0.90 to } 4.12) \\
0.06\end{array}$ & $\begin{array}{l}0.51 \text { (0.23 to } 1.15) \\
0.10\end{array}$ & $\begin{array}{l}0.59(0.27 \text { to } 1.27) \\
0.18\end{array}$ \\
\hline \multicolumn{5}{|l|}{ Income } \\
\hline 10 or more $\mathrm{MW}$ & 1 & 1 & 1 & 1 \\
\hline 4 a $9 \mathrm{MW}$ & $\begin{array}{l}1.71 \text { (0.62 to } 4.67) \\
0,29\end{array}$ & $\begin{array}{l}2.16 \text { (0.89 to } 5.23) \\
0.08\end{array}$ & $\begin{array}{l}1.16 \text { (0.39 to } 3.76) \\
0.79\end{array}$ & $\begin{array}{l}2.43 \text { (0.93 to } 5.88) \\
0.06\end{array}$ \\
\hline 1 a $3 \mathrm{MW}$ & $\begin{array}{l}1.85 \text { (0.67 to 5.04) } \\
0.22\end{array}$ & $\begin{array}{l}0.87 \text { (0.41 to } 1.86) \\
0.73\end{array}$ & $\begin{array}{l}1.30(0.40 \text { to } 4.24) \\
0.66\end{array}$ & $\begin{array}{l}1.12(0.38 \text { to } 3.26) \\
0.88\end{array}$ \\
\hline \multicolumn{5}{|l|}{ Level of physical activity } \\
\hline Active & 1 & 1 & 1 & 1 \\
\hline Sedentary & $\begin{array}{l}1.18 \text { (0.62 to } 2.23) \\
0.60\end{array}$ & $\begin{array}{l}1.90(1.12 \text { to } 3.23) \\
0.01\end{array}$ & $\begin{array}{l}0.86(0.41 \text { to } 1,80) \\
0.70\end{array}$ & $\begin{array}{l}0.97(0.76 \text { to } 1.25) \\
0.85\end{array}$ \\
\hline
\end{tabular}

PCS, physical components summary; MCS, mental components summary; MW, minimum wage.

to use different reference points to evaluate their HRQoL than the younger ones. Older people tend to minimise the negative aspects of situations by giving them neutrality compared with young adults. In addition, changes in expectations about health and life may explain the lack of association. Older age can be seen as a period of life in which the participant is free to explore personal fulfilment, leisure and more autonomy of structured functions (eg, parenthood). ${ }^{27}$

In this study, the low level of schooling was associated, in both sexes, with the physical dimension of HRQoL, also evidenced in other investigations. ${ }^{9} 1928$ The reason that the less educated have smaller HRQoL may be due to lower health perception, less access to health services and lower income. ${ }^{29}$ Low level of schooling is associated with unhappiness due to the fact that these individuals have poor social relations and self-assessed health problems, and education is an important indicator that can directly or indirectly influence HRQoL scores, ${ }^{7}$ mainly through their association with social class and income.

Sedentary lifestyle in women was associated with low HRQoL in PCS. Other studies have already shown 
that regular physical activity is associated with a better HRQoL, ${ }^{20} 30$ while others have shown the opposite. ${ }^{31}$ Physical activity has positive effects on prevention, rehabilitation of diseases, reduction of mortality, increase of physical perception of health and quality of life in general. ${ }^{3233}$ In addition, it is believed that the endorphins released by most active women during physical activity can in themselves justify the well-being and the more positive vision of these women compared with those who are sedentary. ${ }^{34}$

In this study, the widowed and separated marital status of men was associated with the mental/emotional dimension while in other investigations this fact did not occur in HRQoL. ${ }^{20} 35$

Our results should be interpreted in the context of the limitations of the study. First, it is related to the fact that it is a cross-sectional study, which does not allow the establishment of a temporal relationship between the HRQoL and the independent variables studied. Second, the data were based entirely on interviews, so an inaccurate estimation of data and memory bias is inevitable. Factors such as the mood of the person, time and place of the data collection might have contributed to making the participant under- or overestimate the factors that originate the HRQoL scores. However, this method of data collection may not be a problem, because it is a way of collecting subjective information about various domains of health status perception. Third, diseases or chronic conditions were not included as co-variables because they are considered in previous studies to be negatively correlated with HRQoL and should therefore have been controlled.

Some good points can be cited in this study. First, the scarcity of studies on HRQoL conducted among adults of the general population, without any specific pathology and the non-institutionalised. Second, the adequate methodology for calculating the sample size, taking into account the variation of the scores obtained in the pilot study, besides the draw of the households with probability proportional to the size of the UPAs, which is a method indicated for population research. Third, the use of structured methods for the collection and interpretation of data contributed to the internal validity of our conclusions. Finally, the possibility of reproducing the present study and making use of statistical analysis, allowing reliability and inferences.

Future research is needed in order to develop an understanding of HRQoL and adult well-being, including concurrent physical, social, cultural and behavioural variables such as social capital, occurrence of psychic disorders, access to health services, job satisfaction, family composition, religiosity and spirituality are variables which remain scarcely explored in relation to HRQoL.

\section{CONCLUSION}

In this study it was observed that women have lower mean scores than men in all domains. That ageing affects negatively the physical and mental components of HRQoL.
That the less educated have low physical dimension scores; that sedentary women presented lower scores in the physical domains; and being widowed and separated was associated with lower MSCs.

\section{Author affiliations}

${ }^{1}$ Physiotherapy Department, Universidade do Sagrado Coração, Bauru, São Paulo, Brazil

${ }^{2}$ Physiotherapy Department, Universidade do Sagrado Coração, Bauru, São Paulo, Brazil

${ }^{3}$ Physiotherapy Department, Public Health Graduate Programme, Universidade do Sagrado Coração (USC), Bauru, São Paulo, Brazil

${ }^{4}$ Physiotherapy Department, Universidade do Sagrado Coração (USC), Bauru, São Paulo, Brazil

${ }^{5}$ Department of Biostatistics, Universidade Estadual Paulista, Botucatu, São Paulo, Brazil

${ }^{6}$ Physiotherapy Department, Universidade do Sagrado Coração, Bauru, São Paulo, Brazil

Contributors NMM conducted data collection, analysis and interpretation of data and preparation of the manuscript. MHSC coordinated data collection and drafted the manuscript. SFAPS participated in the statistical analysis and preparation of the manuscript. CVSG participated in the design of the study and statistical analysis. JEC participated in the design of the study, analysis and interpretation of data and preparation of the manuscript. AV participated in the design and coordination of the study, analysis and interpretation of data and preparation of the manuscript. All authors read and approved the final manuscript.

Funding This study was supported by funding from the FAPESP (Fundação de Amparo à Pesquisa do Estado de São Paulo)

Competing interests None declared.

Patient consent Obtained.

Ethics approval Comitê de Ética em Pesquisa com Seres Humanos da Universidade do Sagrado Coração. The study was submitted to the Ethics Committee in Research with Human Beings at the Universidade do Sagrado Coração (USC), in line with the principle announced in the Declaration of Helsinki and in accordance with Resolution 196/96 and 251/97 of the National Health Council. The study was approved by the Ethics Committee in Research of the Universidade do Sagrado Coração (USC): n²01/11.

Provenance and peer review Not commissioned; externally peer reviewed.

Data sharing statement The authors state that shared data in the link: and there is no additional data of the study.

Open Access This is an Open Access article distributed in accordance with the Creative Commons Attribution Non Commercial (CC BY-NC 4.0) license, which permits others to distribute, remix, adapt, build upon this work non-commercially, and license their derivative works on different terms, provided the original work is properly cited and the use is non-commercial. See: http://creativecommons.org/ licenses/by-nc/4.0/

(c) Article author(s) (or their employer(s) unless otherwise stated in the text of the article) 2018. All rights reserved. No commercial use is permitted unless otherwise expressly granted.

\section{REFERENCES}

1. The WHOQOL Group. The World Health Organization Quality of Life assessment (WHOQOL): position paper from the World Health Organization. Soc Sci Med 1995;41:1403-10.

2. Capela C, Marques AP, Assumpção A, et al. Associação da qualidade de vida com dor, ansiedade e depressão. Fisioterapia e Pesquisa 2009;16:263-8.

3. Salaffi F, De Angelis R, Stancati A, et al. Health-related quality of life in multiple musculoskeletal conditions: a cross-sectional populationbased epidemiological study. II. The MAPPING study. Clin Exp Rheumatol 2005;23:829-39.

4. Carta MG, Aguglia E, Caraci F, et al. Quality of life and urban/rural living: preliminary results of a community survey in Italy. Clin Pract Epidemiol Ment Health 2012;8:169-74. 
5. Laguardia J, Campos MR, Travassos C, et al. Dados normativos brasileiros do questionario Short Form-36 versao 2. Rev Bras Epidemiol 2013;16:889-97.

6. Alves MCGP. Técnicas de replicação em análise de dados de inquéritos domiciliares. (Tese de Doutorado). São Paulo: Faculdade de Saúde Pública da USP, 2002.

7. Aghamolaei T, Tavafian SS, Zare S. Determinants of health-related quality of life on people living in Bandar Abbas, Iran. Iran J Public Health 2011;40:128-35.

8. Vathesatogkit P, Sritara P, Kimman M, et al. Associations of lifestyle factors, disease history and awareness with health-related quality of life in a Thai population. PLoS One 2012;7:e49921-9.

9. Cruz LN, Fleck MP, Oliveira MR, et al. Health-related quality of life in Brazil: normative data for the SF-36 in a general population sample in the south of the country. Cien Saude Colet 2013;18:1911-21.

10. Pinto VG. Saúde bucal coletiva. 4th edn. São Paulo: Editora Santos, 2000.

11. Reisine ST, Bailit HL. Clinical oral health status and adult perceptions of oral health. Soc Sci Med Med Psychol Med Sociol 1980;14A:597-605.

12. Ciconelli RM, Ferraz MB, Santos W, et al. Tradução para a língua Portuguesa e validação do questionário genérico de avaliação de qualidade de vida SF 36. Rev Bras Reum 1999;39:143-50.

13. Matsudo SMM, Araújo TL, Matsudo VKR, et al. Questionário Internacional de Atividade Física (IPAQ): estudo de validade e reprodutibilidade no Brasil. Rev Bras Ativ Fís e Saúde 2001;6:5-18.

14. Matsudo SMM, Matsudo VKR, Araújo TL, et al. Nível de atividade física na população do estado de São Paulo: uma análise de acordo com o gênero, idade, nível sócioeconômico, distribuição geográfica e de conhecimento. Rev Bras Ciê e Mov 2002;10:41-50.

15. HHS - Physical Activity Guidelines Advisory Committee. 2008. Physical activity guidelines advisory committee report. Washington, DC: U.S.

16. Instituto Brasileiro de geografia e estatística. Síntese de indicadores sociais: uma análise das condições de vida da população Brasileira. Rio de Janeiro, 2012.

17. Norman GR, Streiwner DL. Biostatitics: the base essentials, mosbyyear book. St. lowis, 1994

18. Victora CG, Huttly SR, Fuchs SC, et al. The role of conceptual frameworks in epidemiological analysis: a hierarchical approach. Int J Epidemiol 1997;26:224-7.

19. Marcelo M, Ciconelli RM, Ferraz MB. Quality of life among the Brazilian adult population using the generic SF-8 questionnaire. Rio de Janeiro: Cad. Saúde Pública, 2011;27:1121-31.

20. Noronha DD, Martins AM, Dias DS, et al. Factors in adult healthrelated quality of life: a population-based study. Cien Saude Colet 2016;21:463-74.
21. Durán-Arenas L, Gallegos-Carrillo K, Salinas-Escudero G, et al . Hacia una base normativa Mexicana en la medición de calidad de vida relacionada con la salud, mediante el Formato Corto 36. Salud Publica Mex 2004:46:306-15.

22. García HI, Vera CY, Lugo LH. Calidad de vida relacionada con la salud en Medellín y su área metropolitana, con aplicación del SF-36. Rev Fac Nac Salud Pública 2013;32:26-39.

23. Neyra OT. Elaboración de una Base Normativa para Medir la Calidad de Vida Relacionada con la Salud en Usuarios de EsSalud mediante el SF 36. v1 Huacho, 2009.

24. Saeed AA, Al-Hamdan NA, Bahnassy AA, et al. Prevalence, awareness, treatment, and control of hypertension among Saudi adult population: a national survey. Int J Hypertens 2011;2011:1-8.

25. Ma X, McGhee SM. A cross-sectional study on socioeconomic status and health-related quality of life among elderly Chinese. BMJ Open 2013;3:e002418.

26. Netuveli G, Wiggins RD, Hildon Z, et al. Functional limitation in long standing illness and quality of life: evidence from a national survey. BMJ 2005;331:1382-3.

27. Datta P, Datta D, Majumdar K. Association of quality of life of urban elderly with socio-demographic factors. Int J Med Public Health 2015;5:274-8.

28. Flor LS, Campos MR, Laguardia J, et al. Posição social e grupos ocupacionais no Brasil: evidência de uma pesquisa de base populacional. Rev Bras Epidemiol 2013;16:748-62.

29. Kontodimopoulos N, Pappa E, Niakas D, et al. Validity of SF-12 summary scores in a Greek general population. Health Qual Life Outcomes 2007;5:55.

30. Farid M, Dabiran S. Health-related quality of life in Iranian women with different levels of physical activity. Asian J Sports Med 2012;3:203-7.

31. van Oostrom SH, Smit HA, Wendel-Vos GC, et al. Adopting an active lifestyle during adulthood and health-related quality of life: the Doetinchem Cohort Study. Am J Public Health 2012;102:e62-8.

32. Sarwer DB, Moore RH, Diewald LK, et al. The impact of a primary care-based weight loss intervention on the quality of life. Int $J$ Obes 2013;37(Suppl 1):S25-30.

33. Anokye NK, Trueman P, Green C, et al. Physical activity and healthrelated quality of life. BMC Public Health 2012;12:624.

34. Costa VB, Soares NIS, Costa JES, et al. Level of physical activity and quality of life of administrative public officials. Biomotriz, 2014;8:2317-3467

35. Lima MG, Barros MB, César CL, et al. Health-related quality of life among the elderly: a population-based study using SF-36 survey. Cad Saude Publica 2009;25:2159-67. 